\title{
Editorial
}

Complications

Diabetes Metab J 2012;36:345-349

http://dx.doi.org/10.4093/dmj.2012.36.5.345

pISSN 2233-6079 • eISSN 2233-6087

DIABETES \& METABOLISM JOURNAL

\section{C-Peptide and Vascular Complications in Type 2 Diabetic Subjects}

\author{
Seok Man Son \\ Department of Internal Medicine, Pusan National University School of Medicine, Yangsan, Korea
}

C-peptide is a small peptide comprised of 31 amino acids, with a short half-life of approximately 30 minutes. It was first identified by Steiner et al. [1] as a by-product of proinsulin and its main role is in assisting in the arrangement of the correct structure of insulin. Proinsulin consists of an A chain, connecting peptide (C-peptide), and B chain. C-peptide has a central glycine-rich region that allows the correct positioning of the $\mathrm{A}$ and $B$ chains for insulin to achieve its tertiary structure [1]. It is secreted into the bloodstream in equimolar amounts together with insulin in response to glucose stimulation. C-peptide has been long considered an inactive peptide; however, over the last two decades, numerous studies have revealed that Cpeptide displays a physiological role in different cell types $[2,3]$. The C-terminal pentapeptide of C-peptide obtains the full activity of intact C-peptide in stimulating $\mathrm{Na}^{+} / \mathrm{K}^{+}$-ATPase [4]. The amino acid sequence of C-peptide can vary by species, although it has several conserved sequences, such as its N-terminal acidic region, glycine-rich central segment, and C-terminal pentapeptide [5]. Moreover, evidence indicates that Cpeptide is not merely an inactive by-product of insulin biosynthesis but also a hormonally-active peptide itself $[3,4]$.

The delta C-peptide value, which postprandial serum Cpeptide levels minus fasting serum C-peptide levels, correlates closely with glucagon-stimulated C-peptide concentrations and decreases progressively as diabetic duration increases $[5,6]$. Approximately $5 \%$ of pancreatic C-peptide is excreted in the urine [7]. Twenty-four-hour urine collections have been shown to correlate well with serum C-peptide measurements; however, they are cumbersome and prone to incomplete urine collection [8]. Post-meal urine C-peptide creatinine ratios have been shown to have similar sensitivity and specificity to glucagon-stimulated serum C-peptide values in classifying diabetes by insulin requirement, but have otherwise been studied little [9]. Urine C-peptide collected in boric acid has recently been shown to be stable for 72 hours at room temperature with no decline in C-peptide levels over this time [10]. The urine Cpeptide creatinine ratio may thus have the potential to provide a simple practical measurement of insulin secretion for use in routine clinical practice.

The Diabetes Control and Complications Trial showed that the residual secretion of serum C-peptide decreased the incidence of diabetic retinopathy and nephropathy in subjects with type 1 diabetes [11]. In a recent cross sectional study, 471 type 1 diabetic patients were followed from 1994 to 2004 [12]. Those subjects with the lowest fasting C-peptide levels were found to have the highest rate of microvascular complications. No association was observed between C-peptide levels and macrovascular complications. There is increasing evidence that, in type 1 diabetic patients, the conservation of residual beta cell function slows microvascular complications, by improving blood glucose control and by the preservation of residual C-peptide secretion.

The effects of C-peptide include a positive influence on longterm complications in type 1 diabetic patients. Some groups
Corresponding author: Seok Man Son

Department of Internal Medicine, Pusan National University School of

Medicine, and Diabetes Center and Endocrine Clinic, Pusan National

University Yangsan Hospital, 20 Geumo-ro, Mulgeum-eup, Yangsan 626-770,

Korea

E-mail: sonsm@pusan.ac.kr
This is an Open Access article distributed under the terms of the Creative Commons Attribution Non-Commercial License (http://creativecommons.org/licenses/by-nc/3.0/) which permits unrestricted non-commercial use, distribution, and reproduction in any medium, provided the original work is properly cited. 
have shown that C-peptide administration in type 1 diabetes results in amelioration of diabetes-induced renal and nerve dysfunction. C-peptide treatment for 6 months has been shown to improve sensory nerve function $[13,14]$. Furthermore, beneficial effects by C-peptide replacement on renal function and structure in type 1 diabetes have been reported $[15,16]$. Given that C-peptide increases capillary blood flow in type 1 diabetic patients, Wallerath et al. [17] demonstrated in vitro that Cpeptide stimulates the release of nitric oxide (NO) from endothelial NO synthase (eNOS) in endothelial cells, and that this effect is mediated by inducting a $\mathrm{Ca}^{2+}$ influx into the cells. In the kidney, C-peptide supplementation suppresses diabetesinduced abnormal renal eNOS expression. This downregulation may explain C-peptide's beneficial effects on diabetic nephropathy [18]. C-peptide has an impact on diabetic neuropathy via improvements to endoneural blood flow and axonal swelling [19], or its improvements to decreased blood flow in the extremities [20]. Several studies have proposed a direct role of endogenous insulin and C-peptide in the improvement of endothelial dysfunction [21]. Moreover, C-peptide increases NO production through ERK1/2 MAP kinase-dependent upregulation of eNOS gene transcription [22].

In contrast to these studies in type 1 diabetes, several studies [23-25] have reported conflicting results on the association between serum C-peptide levels and vascular complications in type 2 diabetes. Yoon et al. [26] reported that the stimulated $\mathrm{C}$-peptide value response to glucagon is associated with microvascular complications to a greater extent than the basal Cpeptide level in subjects with type 2 diabetes. Recently, Bo et al. [27] analyzed a representative cohort of 2,113 subjects with type 2 diabetes mellitus, and a subgroup of 931 individuals from this cohort without chronic complications at baseline, recruited from a diabetes clinic. They found that higher baseline Cpeptide levels were associated with a reduced risk of incident microvascular complications, but imparted no survival benefit to subjects with type 2 diabetes mellitus. Further large prospective studies are needed to clarify the association between Cpeptide and microvascular complications in type 2 diabetic subjects.

Subjects with metabolic syndrome or type 2 diabetes exhibit a greater propensity for the development of a scattered and extensive pattern of arteriosclerosis [28]. Typically, these insulin resistant subjects demonstrate higher serum levels of insulin and C-peptide. Recent data suggest that C-peptide binds to specific, yet unidentified, cell surface receptors. First reports about C-peptide deposition in the vessel wall came from Marx et al. [29], when they demonstrated the deposition of C-peptide in the subendothelial space in the thoracic aorta in diabetic subjects. In that study, C-peptide deposition was found in the intima of the vessel wall in the thoracic aorta of diabetic subjects. Among 21 subjects with C-peptide deposition, 77\% showed infiltration of monocytes/macrophages and 57\% infiltration of CD4+ lymphocytes [29]. These data suggest that Cpeptide deposition may precede monocyte and $\mathrm{T}$ cell migration into the vessel wall. Based on this observation, the hypothesis was raised that C-peptide may deposit in the vessel wall during early atherogenesis, and then through chemotactic effects may promote the recruitment of monocytes and CD4+ lymphocytes. In addition to its chemotactic effect, interesting data exists that suggest that in monocyte-like ThP1 cells, Cpeptide increases the expression of the PPAR $\gamma$-regulated gene CD36, an important scavenger receptor for the macrophage uptake of oxidized low density lipoprotein in arteriosclerotic lesions [30]. These data suggest that C-peptide may also promote the differentiation of monocyte/macrophages towards foam cells, thus representing another potential proatherogenic effect of C-peptide. Patients with early type 2 diabetes and insulin resistance show greater levels of C-peptide in the blood. Together with increased endothelial dysfunction, this leads to the deposition of C-peptide in the intima of the vessel wall. According to in vitro results, C-peptide may have a chemotactic effect on the inflammatory cells involved in the onset of the atherosclerosis, such as monocytes/ macrophages and CD4+ lymphocytes. Further, C-peptide has an effect on the proliferation of smooth muscle cells in the media. These cells migrate into developing atheroma and together with inflammatory cell recruitment represent an initial step in the development of atherosclerosis.

Vascular smooth muscle cells (VSMCs) play a critical role in the development of arteriosclerotic plaques by proliferating and subsequently moving from the media into early lesions and fatty streaks [31]. VSMCs are also important in restenosis formation after coronary intervention. After vascular injury, these cells start to proliferate and then they migrate into the developing neointima. Thus, they become the major cellular substrate for restenotic tissue [32,33]. Several mechanisms, such as platelet-derived growth factor release from activated platelets, secretion of cytokines, and growth factors from inflammatory cells, have been shown to induce VSMC proliferation during atherogenesis and restenosis formation [31]. Since 
C-peptide also co-localizes with VSMCs in the media of early arteriosclerotic lesions in some diabetic subjects, it has been suggested that C-peptide could also exhibit biological activity in these cells [34]. Walcher et al. [35] showed that high levels $(10 \mathrm{nmol} / \mathrm{L})$ of C-peptide induces proliferation of human and rat smooth muscle cells in a concentration-dependent manner, as assessed by Ki-67 assay and thymidine incorporation assay. In addition, C-peptide induces phosphorylation of protein tyrosine kinase (Src) and PI-3 kinase and induces activation of ERK1/2 MAP kinase. VSMC proliferation by extracellular stimuli takes place in the mid-tolate G1 phase of the cell cycle, where D-type cyclins promote G1- to S-phase transition leading to $\mathrm{Rb}$ phosphorylation [36]. Walcher et al. [35] showed that C-peptide increases cyclin D1 expression and Rb phosphorylation, suggesting that $\mathrm{C}$-peptide acts via similar signaling pathways. In another study, insulin did not alter endothelial cell (EC) proliferation or migration, whereas C-peptide (10 $\mathrm{nmol} / \mathrm{L}$ ) stimulated EC proliferation by $40 \%$ [37].

Serum levels of C-peptide are associated with metabolic syndrome in subjects with type 2 diabetes and in subjects with nephropathy and vascular disease [38]. C-peptide is eliminated from the body by the kidneys [38]. In the period of insulin resistance and early type 2 diabetes, elevated levels of C-peptide circulate through the glomeruli and could deposit in the juxtaglomerular apparatus, and from there could have a mitogenetic effect on mesangial cells.

The majority of data described above suggest that C-peptide may promote lesion development in subjects with type 2 diabetes and insulin resistance, while the application of C-peptide in type 1 diabetic subjects who lack C-peptide has been shown to improve diabetic microvascular complications such as diabetic neuropathy. The potential proatherogenic action of Cpeptide is not in conflict with the clinical benefits of C-peptide treatment in subjects with type 1 diabetes. Comparing situations, supplementation of C-peptide in type 1 diabetic subjects may be beneficial, whereas in subjects with insulin resistance and type 2 diabetes, increased levels of C-peptide may be harmful. Further studies in animal models of arteriosclerosis are warranted to examine whether the hypothesis of C-peptide's proatherogenic effects holds true in vivo. Moreover, additional work is needed to identify the C-peptide receptor to better understand and modulate the physiological function of C-peptide.

In conclusion, C-peptide might contribute to the initiation and progression of vascular lesions in diabetic patients. Fur- ther understanding of these mechanisms may pave the way for future therapies that target vascular disease in subjects with diabetes.

\section{CONFLICTS OF INTEREST}

No potential conflict of interest relevant to this article was reported.

\section{REFERENCES}

1. Steiner DF, Cunningham D, Spigelman L, Aten B. Insulin biosynthesis: evidence for a precursor. Science 1967;157:697-700.

2. Wahren J, Shafqat J, Johansson J, Chibalin A, Ekberg K, Jornvall $\mathrm{H}$. Molecular and cellular effects of C-peptide: new perspectives on an old peptide. Exp Diabesity Res 2004;5:15-23.

3. Zhong Z, Kotova O, Davidescu A, Ehren I, Ekberg K, Jornvall $\mathrm{H}$, Wahren J, Chibalin AV. C-peptide stimulates $\mathrm{Na}+, \mathrm{K}+-$ ATPase via activation of ERK1/2 MAP kinases in human renal tubular cells. Cell Mol Life Sci 2004;61:2782-90.

4. Munte CE, Vilela L, Kalbitzer HR, Garratt RC. Solution structure of human proinsulin C-peptide. FEBS J 2005;272:4284-93.

5. Prando R, Odetti P, Melga P, Giusti R, Ciuchi E, Cheli V. Progressive deterioration of beta-cell function in nonobese type 2 diabetic subjects. Postprandial plasma C-peptide level is an indication of insulin dependency. Diabetes Metab 1996;22:185-91.

6. Haupt E, Haupt A, Herrmann R, Benecke-Timp A, Vogel H, Walter C. The KID Study V: the natural history of type 2 diabetes in younger patients still practising a profession. Heterogeneity of basal and reactive C-peptide levels in relation to BMI, duration of disease, age and HbA1. Exp Clin Endocrinol Diabetes 1999;107:236-43.

7. Horwitz DL, Rubenstein AH, Katz AI. Quantitation of human pancreatic beta-cell function by immunoassay of C-peptide in urine. Diabetes 1977;26:30-5.

8. Aoki Y. Variation of endogenous insulin secretion in association with treatment status: assessment by serum C-peptide and modified urinary C-peptide. Diabetes Res Clin Pract 1991;14: 165-73.

9. Hills CE, Brunskill NJ, Squires PE. C-peptide as a therapeutic tool in diabetic nephropathy. Am J Nephrol 2010;31:389-97.

10. McDonald TJ, Knight BA, Shields BM, Bowman P, Salzmann MB, Hattersley AT. Stability and reproducibility of a single-sample urinary C-peptide/creatinine ratio and its correlation with 24-h urinary C-peptide. Clin Chem 2009;55:2035-9. 
11. Steffes MW, Sibley S, Jackson M, Thomas W. Beta-cell function and the development of diabetes-related complications in the diabetes control and complications trial. Diabetes Care 2003; 26:832-6.

12. Panero F, Novelli G, Zucco C, Fornengo P, Perotto M, Segre O, Grassi G, Cavallo-Perin P, Bruno G. Fasting plasma C-peptide and micro- and macrovascular complications in a large clinicbased cohort of type 1 diabetic patients. Diabetes Care 2009;32: 301-5.

13. Ekberg K, Brismar T, Johansson BL, Jonsson B, Lindstrom P, Wahren J. Amelioration of sensory nerve dysfunction by CPeptide in patients with type 1 diabetes. Diabetes 2003;52:53641.

14. Ekberg K, Brismar T, Johansson BL, Lindstrom P, Juntti-Berggren L, Norrby A, Berne C, Arnqvist HJ, Bolinder J, Wahren J. C-Peptide replacement therapy and sensory nerve function in type 1 diabetic neuropathy. Diabetes Care 2007;30:71-6.

15. Samnegard B, Jacobson SH, Jaremko G, Johansson BL, Ekberg K, Isaksson B, Eriksson L, Wahren J, Sjoquist M. C-peptide prevents glomerular hypertrophy and mesangial matrix expansion in diabetic rats. Nephrol Dial Transplant 2005;20:532-8.

16. Sjoquist M, Huang W, Johansson BL. Effects of C-peptide on renal function at the early stage of experimental diabetes. Kidney Int 1998;54:758-64.

17. Wallerath T, Kunt T, Forst T, Closs EI, Lehmann R, Flohr T, Gabriel M, Schafer D, Gopfert A, Pfutzner A, Beyer J, Forstermann U. Stimulation of endothelial nitric oxide synthase by proinsulin C-peptide. Nitric Oxide 2003;9:95-102.

18. Kamikawa A, Ishii T, Shimada K, Makondo K, Inanami O, Sakane N, Yoshida T, Saito M, Kimura K. Proinsulin C-peptide abrogates type-1 diabetes-induced increase of renal endothelial nitric oxide synthase in rats. Diabetes Metab Res Rev 2008;24: 331-8.

19. Sima AA, Zhang W, Grunberger G. Type 1 diabetic neuropathy and C-peptide. Exp Diabesity Res 2004;5:65-77.

20. Forst T, Kunt T, Wilhelm B, Weber MM, Pfutzner A. Role of C-peptide in the regulation of microvascular blood flow. Exp Diabetes Res 2008;2008:176245.

21. Joshua IG, Zhang Q, Falcone JC, Bratcher AP, Rodriguez WE, Tyagi SC. Mechanisms of endothelial dysfunction with development of type 1 diabetes mellitus: role of insulin and C-peptide. J Cell Biochem 2005;96:1149-56.

22. Kitamura T, Kimura K, Makondo K, Furuya DT, Suzuki M, Yoshida T, Saito M. Proinsulin C-peptide increases nitric oxide production by enhancing mitogen-activated protein-kinase- dependent transcription of endothelial nitric oxide synthase in aortic endothelial cells of Wistar rats. Diabetologia 2003;46: 1698-705.

23. Bo S, Cavallo-Perin P, Gentile L, Repetti E, Pagano G. Relationship of residual beta-cell function, metabolic control and chronic complications in type 2 diabetes mellitus. Acta Diabetol 2000;37:125-9.

24. Sari R, Balci MK. Relationship between C peptide and chronic complications in type-2 diabetes mellitus. J Natl Med Assoc 2005;97:1113-8.

25. Kim BY, Jung CH, Mok JO, Kang SK, Kim CH. Association between serum C-peptide levels and chronic microvascular complications in Korean type 2 diabetic patients. Acta Diabetol 2012;49:9-15.

26. Yoon HJ, Cho YZ, Kim JY, Kim BJ, Park KY, Ko GP, Lee DH, Lim DM. Correlations between glucagon stimulated C-peptide levels and microvascular complications in type 2 diabetes patients. Diabetes Metab J 2012;36:379-87.

27. Bo S, Gentile L, Castiglione A, Prandi V, Canil S, Ghigo E, Ciccone G. C-peptide and the risk for incident complications and mortality in type 2 diabetic patients: a retrospective cohort study after a 14-year follow-up. Eur J Endocrinol 2012;167: 173-80.

28. Beckman JA, Creager MA, Libby P. Diabetes and atherosclerosis: epidemiology, pathophysiology, and management. JAMA 2002;287:2570-81.

29. Marx N, Walcher D, Raichle C, Aleksic M, Bach H, Grub M, Hombach V, Libby P, Zieske A, Homma S, Strong J. C-peptide colocalizes with macrophages in early arteriosclerotic lesions of diabetic subjects and induces monocyte chemotaxis in vitro. Arterioscler Thromb Vasc Biol 2004;24:540-5.

30. Al-Rasheed NM, Chana RS, Baines RJ, Willars GB, Brunskill NJ. Ligand-independent activation of peroxisome proliferatoractivated receptor-gamma by insulin and C-peptide in kidney proximal tubular cells: dependent on phosphatidylinositol 3-kinase activity. J Biol Chem 2004;279:49747-54.

31. Ross R. Atherosclerosis: an inflammatory disease. N Engl J Med 1999;340:115-26.

32. Bittl JA. Advances in coronary angioplasty. N Engl J Med 1996; 335:1290-302.

33. Stone GW, Ellis SG, Cox DA, Hermiller J, O'Shaughnessy C, Mann JT, Turco M, Caputo R, Bergin P, Greenberg J, Popma JJ, Russell ME. One-year clinical results with the slow-release, polymer-based, paclitaxel-eluting TAXUS stent: the TAXUSIV trial. Circulation 2004;109:1942-7. 
34. Walcher D, Marx N. C-Peptide in the vessel wall. Rev Diabet Stud 2009;6:180-6.

35. Walcher D, Babiak C, Poletek P, Rosenkranz S, Bach H, Betz S, Durst R, Grub M, Hombach V, Strong J, Marx N. C-peptide induces vascular smooth muscle cell proliferation: involvement of SRC-kinase, phosphatidylinositol 3-kinase, and extracellular signal-regulated kinase 1/2. Circ Res 2006;99:1181-7.

36. Harbour JW, Dean DC. Rb function in cell-cycle regulation and apoptosis. Nat Cell Biol 2000;2:E65-7.
37. Mughal RS, Scragg JL, Lister P, Warburton P, Riches K, O’Regan DJ, Ball SG, Turner NA, Porter KE. Cellular mechanisms by which proinsulin C-peptide prevents insulin-induced neointima formation in human saphenous vein. Diabetologia 2010;53: 1761-71.

38. Mavrakanas T, Frachebois C, Soualah A, Aloui F, Julier I, Bastide D. C-peptide and chronic complications in patients with type-2 diabetes and the metabolic syndrome. Presse Med 2009; 38:1399-403. 